UDC 502.22: 504.3.054

DOI: 10.21668/health.risk/2020.4.13.eng

Research article

\title{
WORKING OUT A PROCEDURE FOR DETERMINING POTENTIALLY HAZARDOUS VOLATILE ORGANIC COMPOUNDS (TRICHLOROETHYLENE AND TETRACHLOROETHYLENE) IN AMBIENT AIR
}

\author{
T.S. Ulanova, T.V. Nurislamova, N.A. Popova, O.A. Mal'tseva \\ Federal Scientific Center for Medical and Preventive Health Risk Management Technologies, 82 Monastyrskaya Str., \\ Perm, 614045, Russian Federation
}

The article dwells on results obtained via experimental research on working out a gas chromatography procedure for determining trichloroethylene and tetrachloroethylene in ambient air. Experiments were performed on substances which had low limits of detection with gas-liquid chromatography with electron capture detection (GLC/ECD) when examined substances were absorbed from ambient air on Tenax TA sorbent. Optimal gas chromatography parameters were established with a hardware-software complex based on «Crystal-5000» gas chromatographer and use of a column from IDBPX-VOL series, $60 \mathrm{~m} \cdot 0.32 \mathrm{~mm} \cdot 1.8 \mu \mathrm{m}$, under the following temperatures: column, $50-230{ }^{\circ} \mathrm{C}$; evaporator, $250{ }^{\circ} \mathrm{C}$; detector, $250^{\circ} \mathrm{C}$.

The developed capillary gas chromatography procedure allows determining trichloroethylene in concentrations ranging from 0.000146 to $0.00146 \mathrm{mg} / \mathrm{m}^{3}$, and tetrachloroethylene, from 0.000081 to $0.00081 \mathrm{mg} / \mathrm{m}^{3}$ with inaccuracy not exceeding $25.0 \%$. We performed metrological assessment of the procedure and it allowed determining quality of analysis results for trichloroethylene and tetrachloroethylene; they were as follows: precision, $21.97 \%$ and $14.3 \%$ : repeatability, $4.22 \%$ and $3.38 \%$; reproducibility, $5.66 \%$ and $4.9 \%$. Limit of detection (LOD) for trichloroethylene and tetrachloroethylene was $C_{\min }=0.0000038 \mathrm{mg} / \mathrm{dm}^{3}$ and $C_{\min }=0.00000083 \mathrm{mg} / \mathrm{dm}^{3}$ accordingly. Limit of quantitative determination (LOQ) was $C_{\text {lim }}=0.000013 \mathrm{mg} / \mathrm{m}^{3}$ for trichloroethylene, and $C_{\text {lim }}=0.0000028 \mathrm{mg} / \mathrm{m}^{3}$ for tetrachloroethylene.

The developed procedure allowed detecting contents of the examined substances in ambient air near a construction site and a dry-cleaner's, trichloroethylene in a range from $0.00001 \mathrm{mg} / \mathrm{m}^{3}$ to $0.0009 \mathrm{mg} / \mathrm{m}^{3}$, tetrachloroethylene, from $0.000011 \mathrm{mg} / \mathrm{m}^{3}$ to $0.00039 \mathrm{mg} / \mathrm{m}^{3}$.

This unified high-sensitive and selective procedure is recommended for systemic control over potentially hazardous volatile organic compounds in ambient air as it allows providing objective and reliable hygienic assessment of chemical safety and quality of the environment and health risk assessment.

Key words: capillary gas chromatography, trichloroethylene, ECD, thermal sorption, LOD, LOQ, tetrachloroethylene, quantitative chemical analysis.

Issues related to chemical safety became a powerful incentive to create an international strategy on providing protection for human health from impacts exerted by adverse environmental factors. A key component in its implementation is risk assessment, i.e., determining an actual threat that damage can be done to human health and the environment ${ }^{1}$.
Health risk assessment methodology is widely used in the Russian Federation as a component in social and hygienic monitoring activities when experts determine priorities in chemical safety of the environment and population. Timely, reliable, and highly precise instrumental laboratory control is a most essential element in correct assessment of the envi-

(C) Ulanova T.S., Nurislamova T.V., Popova N.A., Mal'tseva O.A., 2020

Tatyana S. Ulanova - Doctor of Biological Sciences, Head of the Department for Chemical and Analytical Research Techniques (e-mail: ulanova@ffcrisk.ru; tel.: +7 (342) 233-10-37; ORCID: http://orcid.org/0000-0002-9238-5598).

Tatyana V. Nurislamova - Doctor of Biological Sciences, Deputy Head of the Department for Chemical and Analytical Research Techniques (e-mail: nurtat@fcrisk.ru; tel.: +7 (342) 233-10-37; ORCID: http://orcid.org/0000-0002-2344-3037).

Nina A. Popova - Senior researcher at the Department for Chemical and Analytical Research Techniques (e-mail: malceva@fcrisk.ru; tel.: +7 (342) 233-10-37; ORCID: http://orcid.org/0000-0002-9730-9092).

Olga A. Mal'tseva - Researcher at the Department for Chemical and Analytical Research Techniques (e-mail: malceva@fcrisk.ru; tel.: +7 (342) 233-10-37; ORCID: http://orcid.org/0000-0001-7664-3270).

${ }^{1}$ On the list of priority substances that occur in the environment and their impacts on population health: The information letter dated August 7, 1997 No. 11/109-111. The RF Public Healthcare Ministry, The Department for state sanitaryepidemiologic surveillance. Available at: http://docs.cntd.ru/document/456018733 (24.09.2020) (in Russian). 
ronment and hygienic diagnostics of an existing situation $[1,2]$.

Growing volumes and wider ranges of hazardous chemicals call for up-to-date instrumental research [3]. Special attention should be paid to developing up-to-date procedures for analytical control over toxic compounds and, when necessary, their hazardous metabolites. The most vital issues being discussed at the moment are related to these procedures having sufficient sensitivity, their selectivity, validity, and reproducibility of analytical results ${ }^{2}[4,5]$.

Halogen-containing compounds such as trichloroethylene and tetrachloroethylene are widely used as solvents and degreasing agents in various industries; they are considered to be hazardous for human health [6]. These organic chlorine compounds persist in the environment for a long time and are considered «highly likely carcinogenic» belonging to A2 category A2 [7-9]. Trichloroethylene is a narcotic; when inhaled, its vapors can cause nausea, dizziness, headache, and overall sickness $[10,11]$. As per research data a contact with trichloroethylene results in 6 times higher probability that Parkinson disease might occur [12, 13].

Tetrachloroethylene is toxic when contacted for a long time and produces adverse effects on the central nervous system, liver, and kidneys. Tetrachloroethylene is poorly metabolized in a body as approximately $98 \%$ of it is extracted from the lungs and only $2 \%$ is transformed. Tetrachloroethylene is slowly extracted from a body and is detected 2 weeks after it was inhaled; delay in the lungs is equal to approximately $62 \%[14,15]$.

Our review of scientific literature has revealed that an issue related to assessing contents of trichloroethylene and tetrachloroethylene in ambient air still remains vital. At present there are no highly sensitive and highly selective procedures for determining contents of these potentially toxic compounds [16]. Procedures for analyzing trichloroethylene and tetrachloroethylene contents in ambient air that are described in methodical documents allow determining these compounds in concentrations ranging from 0.001 up to $0.05 \mathrm{mg} / \mathrm{m}^{3}$. In order to improve methodical provision for tests, we fixed a task to measure several compounds using only one selected sample.

Data and methods. Our research objects were ambient air, various procedures for taking ambient air samples, sample preparation procedures, quantitative analysis of ambient air contaminants, as well as efficiency achieved in chromatographic separation of determined compounds on different stationary liquid phases and metrological properties of measuring.

We developed a procedure following several stages: trying-out procedures for taking ambient air samples; examining completeness of extraction; trying-out parameters of gas chromatographic determination and selective separation; determining metrological properties.

Optimal gas chromatographic parameters for determining trichloroethylene and tetrachloroethylene in ambient air were established via capillary gas chromatography performed with «Crystal-5000» chromatographer equipped with a IDBPX-VOL- $60 \mathrm{~m} \cdot 0,32 \mathrm{~mm} \cdot 1,8 \mu \mathrm{m}$ column under the following temperatures: the column, $50-230{ }^{\circ} \mathrm{C}$; vaporizer, $250{ }^{\circ} \mathrm{C}$; detector, $250{ }^{\circ} \mathrm{C}$.

To determine micro-mixtures of toxic volatile organic contaminants (trichloroethylene and tetrachloroethylene) in ambient air, we performed sorption extraction of trichloroethylene and tetrachloroethylene admixtures from ambient air $^{3}$ [17]. This procedure was selected as the most efficient as it allowed extracting and concentrating organic compounds that occurred in the air as gas and vapors $[18,19]$.

\footnotetext{
${ }^{2}$ On sanitary-epidemiologic situation in the Russian Federation in 2007: The State Report. Moscow, 2008,397 p. (in Russian).

${ }^{3}$ GOST R ISO 16017-1-2007. Ambient air, working area air, and air inside closed rooms. Taking samples of volatile organic compounds with a sorption tube with the following thermal desorption and gas chromatography analysis on capillary columns. Part 1. Taking samples via pumping. KODEKS: an electronic fund for legal and reference documentation. Available at: http://docs.cntd.ru/document/1200057637 (27.09.2020) (in Russian).
} 
Ambient air samples were taken on sorption tubes with the following thermal desorption and analysis performed with «Crystal5000» chromatographer.

To build a calibrating curve, we prepared several standard solutions with different concentrations. $1 \mathrm{~mm}^{3}$ of a calibrating solution was introduced on a sorbent in a sorption tube at $10 \mathrm{~mm}$ depth and then thermal desorption was performed.

To assess sensitivity and precision of a procedure for determining trichloroethylene and tetrachloroethylene in ambient air, we established limit of detection (LOD) and limit of quantitative determination (LOQ). To do that, we performed an experiment that involved introducing an analytical standard on a sorption tube with Tenax TA in certain quantities equal to limit of detection and it was repeated for five times.

Limit of detection $C_{\min }$ was taken as being equal to triple value of standard deviation in a background signal that was determined for trichloroethylene and tetrachloroethylene concentrations in an ambient air sample with analytical signal / noise ratio being $>3$. Limit of detection for trichloroethylene and tetrachloroethylene in an ambient air sample was calculated as per the following formula:

$$
\begin{gathered}
C_{\min }= \\
=\frac{\text { background signal value } \cdot \text { analyte concentration }}{\text { value of analytical signal given by analyte }} \times \\
\times 3, \mathrm{mg} / \mathrm{dm}^{3}
\end{gathered}
$$

We performed a metrological assessment of the procedure in order to establish its accuracy, repeatability, intra-laboratory precision, and correctness.

Results and discussion. When determining optimal parameters for selecting the exam- ined compounds, we relied on the following controlling factors: a sorbent covered with stationary liquid phase (SLP) and chromatographer temperature mode $[19,20]$.

We tried out conditions for separating trichloroethylene and tetrachloroethylene from other hydrocarbons with similar physical and chemical properties on capillary columns with different properties of stationary liquid phases: DB-624, HP-FFAP, and HP-VOC. Trichloroethylene and tetrachloroethylene were qualitatively separated on a capillary column IDBPX-VOL-60 $\mathrm{m} \cdot 0.32 \mathrm{~mm} \cdot 1.8 \mu \mathrm{m}$ which was 60 meters long and stationary phase film was $1.8 \mu \mathrm{m}$ thick.

Optimal temperature for gas chromatography analysis was determined via picking-up taking into account boiling temperatures, volatility of the examined compounds, and properties of stationary liquid phases on capillary columns. Bearing in mind that temperature rise on a column produces a positive effect on overall separation process and an amount of time necessary for separation is reduced thus making an overall test shorter, we programmed temperatures at columns thermostat in linear mode when determining organic chlorine compounds.

Gas chromatography parameters are given in Table 1.

Modes 2 and 3 didn't allow achieving efficient trichloroethylene and tetrachloroethylene. Qualitative separation was achieved in Mode 1 and it is recommended for future work (Figure 1).

Gas carrier consumption, $20 \mathrm{~mL} / \mathrm{min}$, was selected during an experiment.

Table 2 contains gas chromatographic analysis properties for standard trichloroethylene and tetrachloroethylene mixtures.

Table 1

Gas chromatography parameters for determining trichloroethylene and tetrachloroethylene in ambient air

\begin{tabular}{|c|c|c|c|}
\hline \multirow{2}{*}{ Mode } & \multicolumn{2}{|c|}{ Temperature, ${ }^{\circ} \mathrm{C}$} & \multirow{2}{*}{ Carrier gas consumption, $\mathrm{mL} / \mathrm{min}$} \\
\cline { 2 - 3 } & Column & Heating rate, ${ }^{\circ} \mathrm{C} / \mathrm{min}$ & 20 \\
\hline 1 & $50-230$ & 10 & 30 \\
\hline 2 & $70-160-180$ & 15 & 30 \\
\hline 3 & $70-160-200$ & 25 & \\
\hline
\end{tabular}




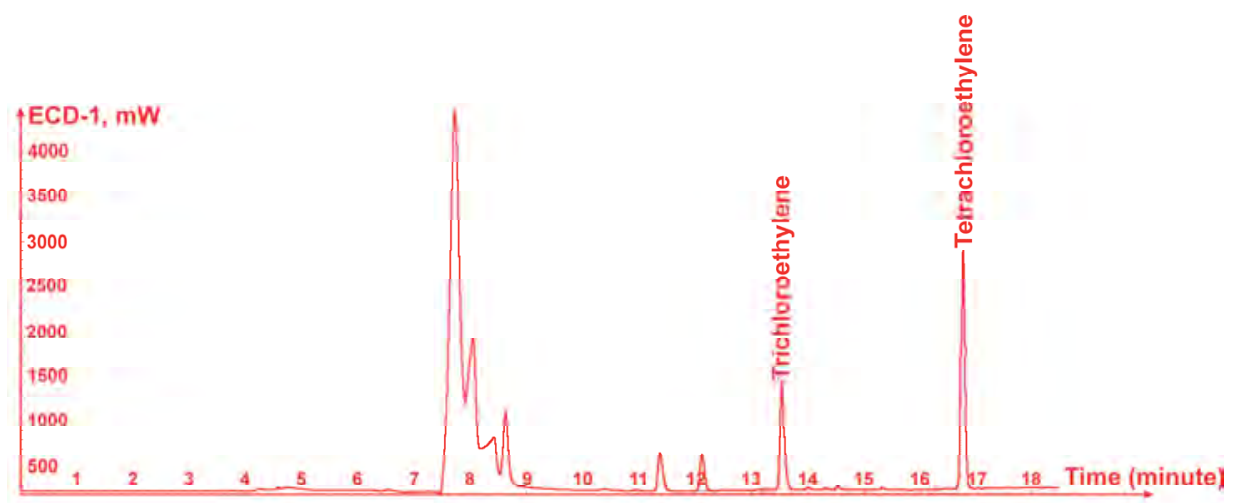

Figure 1. Chromatogram showing a standard trichloroethylene and tetrachloroethylene mixture

Table 2

Gas chromatographic analysis properties for standard trichloroethylene and tetrachloroethylene mixtures

\begin{tabular}{|l|c|c|c|c|}
\hline \multicolumn{1}{|c|}{ Compound } & $\begin{array}{c}\text { SLP, carrier, } \\
\text { fraction }\end{array}$ & Column length, $\mathrm{M}$ & $\begin{array}{c}\text { A sample volume } \\
\text { for analysis, } \mathrm{MM}^{3}\end{array}$ & $\begin{array}{c}\text { Detention time, } \\
\text { min }\end{array}$ \\
\cline { 1 - 5 } Trichloroethylene & \multirow{2}{*}{ ID BPX-VOL } & 60 & 1 & 13.6 \\
\cline { 1 - 2 } Tetrachloroethylene & \multirow{2}{*}{6} & 1 & 16.8 \\
\hline
\end{tabular}

Trichloroethylene and tetrachloroethylene were quantitatively determined via absolute calibration as per 6 series of standard solutions in concentrations varying within $0.0000146-0.000146 \mathrm{mg} / \mathrm{m}^{3}$ for trichloroethylene, and $0.0000081-0.000081 \mathrm{mg} / \mathrm{m}^{3}$ for tetrachloroethylene. Calibrating property was considered stable provided the following condition was met (2) [15]:

$$
S_{\max }-S_{\min } \leq 0,01 \cdot r_{s} \cdot \frac{S_{\max }+S_{\min }}{2},
$$

where $S_{\max }$ is a maximum square of the peak for a corresponding calibration solution, $\mathrm{mW}$;

$S_{\min }$ is a minimum square of the peak for a corresponding calibration solution, $\mathrm{mW}$;

$r_{s}$ is a limit for repeatability of calibration solution square peak; $r_{s}=11.68 \%$ for trichloroethylene and $r_{s}=9.36 \%$ for tetrachloroethylene.

Test results were considered positive provided that the condition (1) was met.

When testing the procedure, we examined how efficient thermal desorption of trichloro- ethylene and tetrachloroethylene was in case different sorbents were used such as CSIII, TTA/CSIII, and Tenax TA. We determined average thermal desorption values for the examined compounds; the results are given in Table 3.

The performed research allowed us to establish that Tenax TA polymer sorbent had optimal properties as the greatest thermal desorption achieved with it amounted to $93 \%$ for trichloroethylene and $95 \%$ for tetrachloroethylene.

To establish validity, we estimated the following parameters: linearity, measurement range, precision (accuracy and reproducibility), and limit of detection ${ }^{4}$. It was established that provided all the necessary conditions were observed and measurements were performed according to the procedure, inaccuracy (and its components) should not exceed values given in Table 4.

Limit of detection LOD for trichloroethylene and tetrachloroethylene amounted to $C_{\min }=0.0000038 \mathrm{mg} / \mathrm{dm}^{3}$ and $C_{\min }=$ $=0.00000083 \mathrm{mg} / \mathrm{dm}^{3}$ accordingly.

\footnotetext{
${ }^{4}$ GOST R ISO 5725-1-2002. Accuracy (correctness and precision) or measuring techniques and results. Part 1. Basic provisions and definitions. KODEKS: an electronic fund for legal and reference documentation. Available at: http://docs.cntd.ru/document/1200029975 (27.09.2020) (in Russian).
} 
Table 3

Average thermal desorption values $(\mu \mathrm{g})$

\begin{tabular}{|c|c|c|c|c|c|c|}
\hline \multirow{2}{*}{ Sorbent } & \multicolumn{2}{|c|}{ Trichloroethylene } & \multirow{2}{*}{$\begin{array}{c}\text { Thermal } \\
\text { desorption, \% }\end{array}$} & \multicolumn{2}{|c|}{ Tetrachloroethylene } & \multirow{2}{*}{$\begin{array}{c}\text { Thermal } \\
\text { desorption, \% }\end{array}$} \\
\hline & introduced & detected & & introduced & detected & \\
\hline 1. CS III & \multirow{3}{*}{0.0048} & $0.00402 \pm 0.0007$ & 83.75 & \multirow{3}{*}{0.004} & $0.0025 \pm 0.0004$ & 62.5 \\
\hline 2. TTA/CS III & & $0.00400 \pm 0.0002$ & 83.3 & & $0.0025 \pm 0.00021$ & 62.5 \\
\hline 3. Tenax TA & & $0.00445 \pm 0.003$ & 93.0 & & $0.0038 \pm 0.00044$ & 95.0 \\
\hline
\end{tabular}

Table 4

Measurement range for trichloroethylene and tetrachloroethylene contents in ambient air, measurement accuracy, correctness, and precision

\begin{tabular}{|c|c|c|c|c|}
\hline Range, $\mathrm{mg} / \mathrm{m}^{3}$ & $\begin{array}{c}\text { Accuracy } \\
\pm \delta, \%\end{array}$ & $\begin{array}{c}\text { Repeatability, } \\
\sigma_{r}, \%\end{array}$ & $\begin{array}{c}\text { Reproducibility, } \\
\sigma_{R}, \%\end{array}$ & $\begin{array}{c}\text { Correctness } \\
\pm \delta_{c}, \%\end{array}$ \\
\hline \multicolumn{5}{|c|}{ Trichloroethylene } \\
\hline $0.0000146-0.000146$ & 22.00 & 4.21 & 5.70 & 19.00 \\
\hline \multicolumn{5}{|c|}{ Tetrachloroethylene } \\
\hline $0.0000081-0.000081$ & 14.30 & 3.40 & 4.90 & 10.60 \\
\hline
\end{tabular}

Limit of quantitative determination for trichloroethylene and tetrachloroethylene in ambient air samples was detected as the lowest concentrations in a standard sample with acceptable precision and reliability that gives an analytical signal (a chromatographic peak) with its height being equal to a 10-time basic noise hindrances level.

Chromatograms for trichloroethylene and tetrachloroethylene in concentrations equal to limit of quantitative determination are given in Figure 2.

Limit of quantitative determination for trichloroethylene and tetrachloroethylene in a standard sample was set higher than limit of detection and amounted to $C_{\lim }=0.000013 \mathrm{mg} / \mathrm{m}^{3}$ for trichloroethylene and $C_{\lim }=0.0000028 \mathrm{mg} / \mathrm{m}^{3}$ for tetrachloroethylene.
To test the procedure and assess trichloroethylene and tetrachloroethylene contents in ambient air samples, ambient air samples were taken in an area where a construction site and a dry-cleaner's were located and then analyzed. Analysis results for samples taken near a construction site are given in Table 5.

Trichloroethylene and tetrachloroethylene were detected in $83 \%$ and $100 \%$ ambient air samples accordingly. There were no samples with their contents exceeding the hygienic standards detected during the observation period.

Table 6 contains the results obtained via analyzing ambient air samples taken in an area where a dry-cleaner's was located.

Analysis of the obtained results revealed that $100 \%$ ambient air samples contained

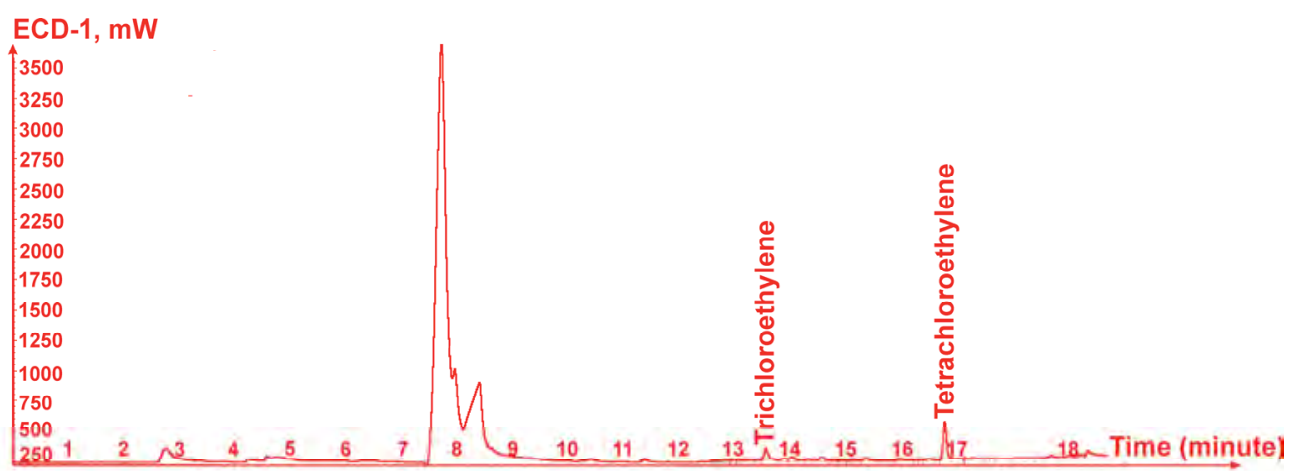

Figure 2. A chromatogram for a standard sample 
Table 5

Results obtained via chemical analysis of ambient air samples performed to determine trichloroethylene and tetrachloroethylene contents in ambient air in an area where a construction site is located

\begin{tabular}{|c|c|c|c|c|c|c|c|}
\hline \multirow{2}{*}{$\begin{array}{c}\text { Compound } \\
\text { to be determined }\end{array}$} & \multirow{2}{*}{$\begin{array}{l}\mathrm{MPC}_{\mathrm{s} . \mathrm{m}} \\
\mathrm{mg} / \mathrm{m}^{3}\end{array}$} & \multicolumn{6}{|c|}{$\mathrm{mg} / \mathrm{m}^{3}$} \\
\hline & & \multicolumn{2}{|c|}{$13: 30$} & \multicolumn{2}{|c|}{$16: 00$} & \multicolumn{2}{|c|}{ 19:00 } \\
\hline $\begin{array}{l}\text { Trichloro- } \\
\text { ethylene }\end{array}$ & 4 & $\begin{array}{l}\text { Lower than } \\
\text { LOD }\end{array}$ & $\begin{array}{l}\text { Lower than } \\
\text { LOD }\end{array}$ & $\begin{array}{c}\text { Lower than } \\
\text { LOD }\end{array}$ & $\begin{array}{l}0.00005 \pm \\
0.000009\end{array}$ & $\begin{array}{c}\text { Lower than } \\
\text { LOD }\end{array}$ & $\begin{array}{c}\text { Lower } \\
\text { than LOD }\end{array}$ \\
\hline $\begin{array}{l}\text { Tetrachloro- } \\
\text { ethylene }\end{array}$ & 0.5 & $\begin{array}{c}0.0000135 \pm \\
0.0000014\end{array}$ & $\begin{array}{l}0.000012 \pm \\
0.0000013\end{array}$ & $\begin{array}{l}0.000021 \pm \\
0.0000022\end{array}$ & $\begin{array}{l}0.000024 \pm \\
0.0000025\end{array}$ & $\begin{array}{l}0.000055 \pm \\
0.0000058\end{array}$ & $\begin{array}{c}0.000085 \pm \\
0.00001\end{array}$ \\
\hline
\end{tabular}

Table 6

Results obtained via chemical analysis of ambient air samples performed to determine trichloroethylene and tetrachloroethylene contents in ambient air in an area where a dry-cleaner's is located

\begin{tabular}{|c|c|c|}
\hline \multirow{2}{*}{$\begin{array}{c}\text { Sample } \\
\text { No. }\end{array}$} & \multicolumn{2}{|c|}{ Ambient air } \\
\cline { 2 - 3 } & Trichloroethylene, & $\begin{array}{c}\text { Tetrachloroethylene } \\
\text { Single maximum MPC }=4 \mathrm{mg} / \mathrm{m}^{3}\end{array}$ \\
\hline 1 & $0.00004 \pm 0.00001$ & $0.00007 \pm 0.000018$ \\
\hline 2 & $0.00002 \pm 0.000005$ & $0.00024 \pm 0.00006$ \\
\hline 3 & $0.00039 \pm 0.000098$ & $0.0001 \pm 0.000025$ \\
\hline 4 & $0.00001 \pm 0.0000025$ & $0.00001 \pm 0.0000025$ \\
\hline 5 & $0.00002 \pm 0.000005$ & $0.00004 \pm 0.00001$ \\
\hline 6 & $0.00003 \pm 0.0000075$ & $0.00006 \pm 0.000015$ \\
\hline 7 & $0.00038 \pm 0.000095$ & $0.00018 \pm 0.000045$ \\
\hline 8 & $0.00013 \pm 0.000033$ & $0.00013 \pm 0.000033$ \\
\hline 9 & $0.00005 \pm 0.000013$ & $0.00004 \pm 0.00001$ \\
\hline 10 & $0.00021 \pm 0.000053$ & $0.00013 \pm 0.000033$ \\
\hline
\end{tabular}

trichloroethylene and tetrachloroethylene. Tetrachloroethylene concentrations detected in a period when screening observation were performed were up to 3 times higher than the lower concentrations range.

Conclusions. We have developed an upto-date gas chromatographic procedure for quantitative chemical analysis of potentially hazardous chemical compounds (trichloroethylene and tetrachloroethylene) in ambient air. Sample preparation for instrumental measuring is aimed at extracting and concentrating organic chlorine compounds out of ambient air on Tenax TA sorbent combined with thermal desorption.

Sensitivity of the procedure varies from 0.000146 to $0.00146 \mathrm{mg} / \mathrm{m}^{3}$ for trichloroethylene and from 0.000081 to $0.00081 \mathrm{mg} / \mathrm{m}^{3}$ for tetrachloroethylene.
The developed procedure has been properly tested and it allowed determining the examined compounds in ambient air near a construction site and a dry-cleaner's, in a range from $0.00001 \mathrm{mg} / \mathrm{m}^{3}$ to $0.0009 \mathrm{mg} / \mathrm{m}^{3}$ for tetrachloroethylene and from $0.000011 \mathrm{mg} / \mathrm{m}^{3}$ to $0.00039 \mathrm{mg} / \mathrm{m}^{3}$ for trichloroethylene.

This unified highly sensitive and selective procedure is recommended for systemic control over potentially hazardous volatile organic compounds (trichloroethylene and tetrachloroethylene) in ambient air; such control is necessary for providing objective and reliable hygienic assessment of environmental chemical safety and health risk assessment.

Funding. The research was not granted any sponsor support.

Conflict of interests. The authors declare there is no any conflict of interests. 


\section{References}

1. Yudina T.V., Fedorova N.E., Volkova V.N., Volchek S.I. Analiticheskie voprosy laboratornoi praktiki kontrolya pestitsidov [Analytical issues in laboratory practices applied to control pesticides]. Faktory riska i zdorov'e naseleniya v regionakh Rossii: nauchnye Trudy FNTsG im. F.F. Erismana. Lipetsk, 2004, vol. 13, pp. 224-227 (in Russian).

2. Rakitskii V.N. Voprosy garmonizatsii metodicheskikh podkhodov v toksikologii [Issues related to harmonizing methodological approaches in toxicology]. Tezisy dokladov vtorogo s"ezda toksikologov Rossii. Moscow, 2003, pp. 219-220 (in Russian).

3. Rakitskii V.N. Problems of contemporary hygiene. Gigiena i sanitariya, 2015, vol. 94, no. 4, pp. 4-7 (in Russian).

4. Rakhmanin Yu. A., Sinitsyna O.O. Status and actualization of tasks to improve the scientificmethodological and regulatory frameworks in the field of human ecology and environmental hygiene. Gigiena i sanitariya, 2013, vol. 92, no. 5, pp. 4-10 (in Russian).

5. Malysheva A.G, Rakhmanin Yu.A. Fiziko-khimicheskie metody kontrolya veshchestv v gigiene okruzhayushchei sredy [Physical and chemical methods for control over substances in environmental hygiene]. Sankt-Peterburg, NPO «Professional» Publ., 2012, 720 p. (in Russian).

6. Doherty R.E. A History of the Production and Use of Carbon Tetrachloride, Tetrachloroethylene, Trichloroethylene and 1,1,1-Trichloroethane in the United States: Part 2-Trichloroethylene and 1,1,1-Trichloroethane. Environmental Forensics, 2000, vol. 1, no. 2, pp. 83-93. DOI: 10.1006/enfo.2000.0011

7. Barton C. Tetrachloroethylene. Encyclopedia of Toxicology, 2014, no. 12, pp. 498-502. DOI: 10.1016/b978-0-12-386454-3.00436-x

8. Davydov M.I., Aksel' E.M. Zabolevaemost' zlokachestvennymi novoobrazovaniyami Rossii i stran SNG v 2006 g. [Morbidity with malignant neoplasms in Russian and CIS countries in 2006]. Vestnik RONTs im. N.N. Blokhina RAMN, 2007, vol. 18, no. 2, pp. 52-90 (in Russian).

9. Uilki Ch., Sammers Dzh., Daniels Ch. Polivinilkhlorid. In: G.E. Zaikova ed. Sankt-Peterburg, TsOP Professiya Publ., 2007, 800 p. (in Russian).

10. Karimov F.K. Pathochemistry of toxic effects of chlororganic and aromatic compounds. Meditsinskii vestnik Bashkortostana, 2007, vol. 2, no. 6, pp. 76-80 (in Russian).

11. Boyer A.S. Trichloroethylene Inhibits Development of Embryonic Heart Valve Precursors in Vitro. Toxicological Sciences, 2000, vol. 53, no. 1, pp. 109-117. DOI: 10.1093/toxsci/53.1.109

12. Stewart R.D., Dodd H.C., Gay H.H., Erley D.S. Experimental Human Exposure to Trichloroethylene, Archives of Environmental Health. An International Journal, 2013, vol. 20, no. 1, pp. 64-71. DOI: 10.1080/00039896.1970.10665543

13. Drake V.J., Koprowski S.L., Hu N., Smith. M., Lough J. Cardiogenic effects of trichloroethylene and trichloroacetic acid following exposure during heart specification of avian development. Toxicological Sciences, 2006, vol. 94, no. 1, pp. 153-162. DOI: 10.1093/toxsci/kfl083

14. Pezzoli G., Cereda E. Exposure to pesticides or solvents and risk of Parkinson disease. Neurology, 2013, vol. 80, no. 22, pp. 2035-2041. DOI: 10.1212/WNL.0b013e318294b3c8

15. Schlichting L.M., Wright P.F.A., Stacey N.H. Effects of tetrachloroethylene on hepatic and splenic lymphocytoxic activities in rodents. Toxicol Ind Health, 1992, vol. 8, no. 5, pp. 255-266. DOI: $10.1016 / 0887-2333(94) 90240-2$

16. Peers A.M. Method 5: Determination of trichloroethylene and tetrachloroethylene in air. IARC Sci, 1985, no. 68, pp. 205-211.

17. Rasmussen R.A., Harsch D.E., Sweany P.H., Krasnec J.P., Cronn D.R. Determination of Atmospheric Halocarbons by A Temperature-Programmed Gas Chromatographic Freezeout Concentration Method. Journal of the Air Pollution Control Association, 1977, vol. 27, no. 6, pp. 579-581. DOI: $10.1080 / 00022470.1977 .10470461$

18. Begerow J., Jermann E., Keles T., Koch T., Dunemann L. Screening method for the determination of 28 volatile organic compounds in indoor and outdoor air at environmental concentrations using dual-column capillary gas chromatography with tandem electron-capture-flame ionization detection. J Chromatogr A, 1996, vol. 749, no. 1-2, pp. 181-191. 
19. Karellas N., Chen Q. Real-Time Air Monitoring of Trichloroethylene and Tetrachloroethylene Using Mobile TAGA Mass Spectrometry. Journal of Environmental Protection, 2013, vol. 4, no. 8A, pp. 99-105. DOI: 10.4236/jep.2013.48A1012

20. Rudenko B.A., Zuev B.K., Nikiforov Yu.V., Naida O.O., Shoromov N.P. Chromatographic capillary columns of non-round cross sections. Zhurnal analiticheskoi khimii, 2005, vol. 60, no. 7, pp. 729-733 (in Russian).

Ulanova T.S., Nurislamova T.V., Popova N.A., Mal'tseva O.A. Working out a procedure for determining potentially hazardous volatile organic compounds (trichloroethylene and tetrachloroethylene) in ambient air. Health Risk Analysis, 2020, no. 4, pp. 113-120. DOI: 10.21668/health.risk/2020.4.13.eng

Received: 09.09.2020

Accepted: 10.12.2020

Published: 30.12.2020 